\title{
The study of biotic interactions in the Brazilian Cerrado as a path to the conservation of biodiversity
}

\section{KLEBER DEL-CLARO and HELENA MAURA TOREZAN-SILINGARDI}

Laboratório de Ecologia Comportamental e de Interações/LECI, Instituto de Biologia, Universidade Federal de Uberlândia, Rua Ceará, s/n, Umuarama, 38400-902 Uberlândia, MG, Brazil

Manuscript received on January 25, 2019; accepted for publication on July 27, 2019

\begin{abstract}
How to cite: DEL-CLARO K AND TOREZAN-SILINGARDI HM. 2019. The study of biotic interactions in the Brazilian Cerrado as a path to the conservation of biodiversity. An Acad Bras Cienc 91: e20180769. DOI DOI 10.1590/0001-3765201920180768.

Abstract: As a focus for conservation efforts, biodiversity has received increased attention in the last fifty years. Searching for patterns in biodiversity, researchers have suggested studies including: ecological communities, cladistics classifications, hierarchical compositions of different levels of organization, and groups of taxonomically related species. Here, we propose that the study of the biodiversity of interactions may present a new perspective in the efforts to conserve biodiversity, especially in endangered ecosystems like the tropical savannas. We suggest that Cerrado, like other tropical savannas, is a particularly important ecosystem in which we can direct efforts to explain what determines the major part of variation in the outcomes of species interactions.
\end{abstract}

Key words: ant-plant interactions, ecosystem, tropical savanna, Veredas.

In tropical South America, the savanna covers about 2 million $\mathrm{km}^{2}$, an area similar to the one occupied by the Western Europe. In Brazil this vegetation is commonly named "Cerrado" and represented ca. $22 \%$ of the Brazilian land surface, being the second largest biome in the country. It extends from the southern borders of the Amazonian forest to outlying areas in the southern states of São Paulo and Paraná. The distribution of the cerrado biome is highly coincident with the plateau of central Brazil, which divides three of the largest South American water basins: those of the Amazon, Plate/Paraguay, and São Francisco rivers (see Oliveira-Filho and Ratter 2002). The Brazilian savanna or Cerrado is

Correspondence to: Kleber Del-Claro

E-mail: delclaro@ufu.br

ORCid: https://orcid.org/0000-0001-8886-9568 the most diverse tropical savanna, and its landscape presents also great variation with several vegetation physiognomies, from open areas with large fields (Figure 1a) up to a close and dry forest with trees reaching 10 to $12 \mathrm{~m}$ tall, the "Cerradão" (Figure 1b); the Cerrado sensu stricto (Figure 1c) composed mainly by shrubs and small tress; and "Veredas" (Figure 1d) or the palm tree wetlands (OliveiraFilho and Ratter 2002). However, Cerrado is considered a hot-spot for biodiversity preservation, as it has lots of endemic species and its area is decreasing very fast due to human activities that result in soil occupation. Nowadays only $8 \%$ of original Cerrado area is still preserved. Despite this importance in area and diversity, research on cerrado is mainly driven to exploit new manners of use, especially for agriculture, livestock or pasture. 


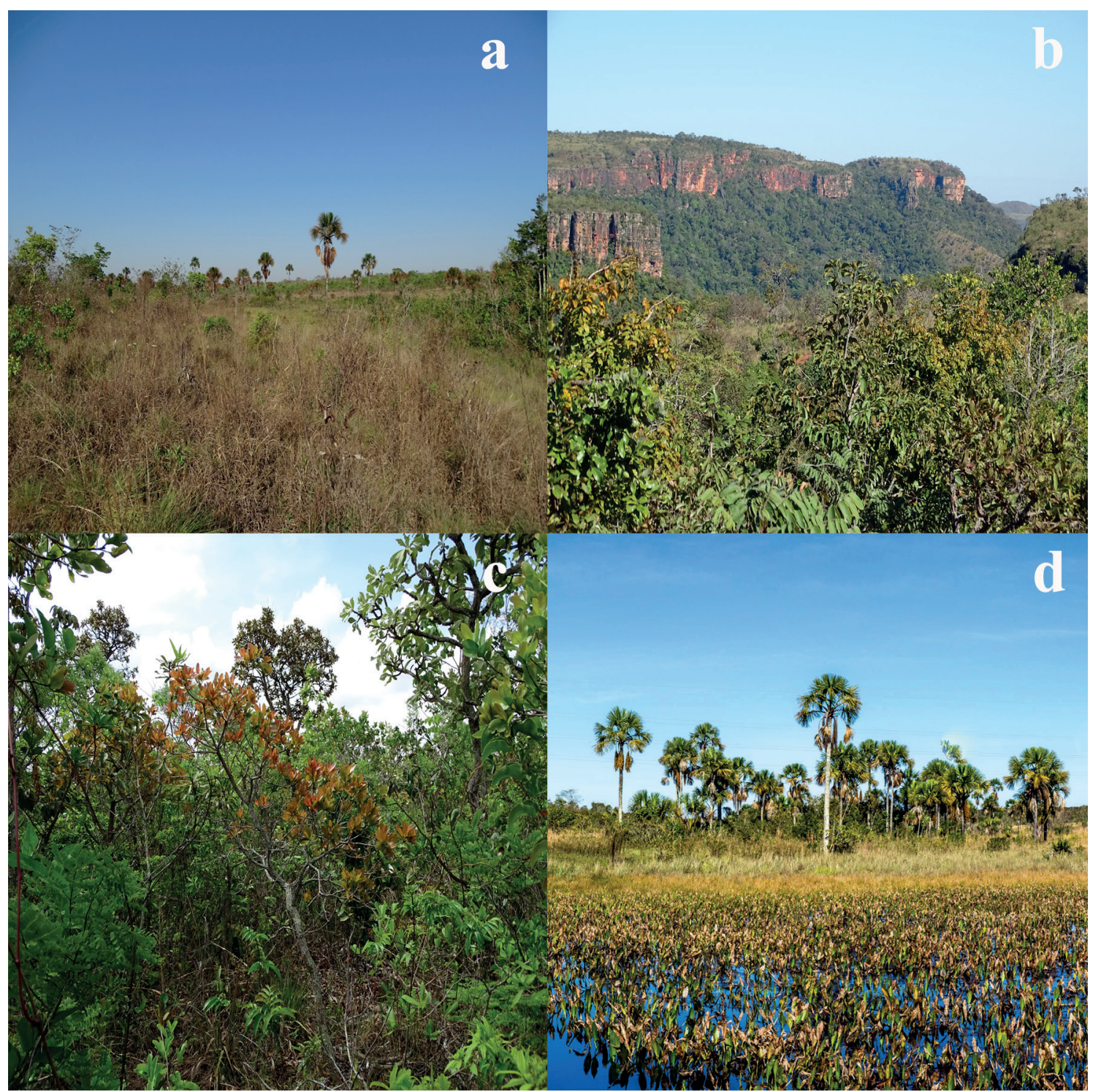

Figure 1 - The most common physiognomies of the Brazilian tropical savannas: a - Open cerrado - opened areas of large fields, in some cases acting as an ecotone between cerrado and veredas; $\mathbf{b}$ - The cerradão, dry forest - tall trees in areas of more compacted soil; $\mathbf{c}$ - The cerrado sensu stricto - shrubs and small tress in a sand soil area; $\mathbf{d}$ - The veredas or palm tree wetlands - in the lower parts of landscape, occurs in high humidity and clay soil.

Studies on biodiversity represent less than $10 \%$ of the total (Oliveira and Marquis 2002, Del-Claro et al. 2018), even with an expressive increase in numbers of papers published in ecology, botany and zoology in recent years.

As a focus for conservation efforts, biodiversity has received increased attention in the last decades of the past century (Pearson 1994), and continues to increase. Searching for patterns in biodiversity, researchers have suggested various units of study including: ecological communities, cladistics classifications, hierarchical composite of different levels of organization, and groups of taxonomically related species (Del-Claro et al. 2018). The majority of programs for conservation of natural systems have been concerned primarily with the maintenance of species diversity, ecosystem function, and the preservation of 
genetic variation within populations (Thompson 2013). Thus a broader view of biodiversity has prevailed. These guidelines have been followed by researchers in the study of Brazil main biomes like Atlantic Forest, Amazonia and also Cerrado (e. g. Oliveira and Marquis 2002, Gottsberger and Silberbauer-Gottsberger 2006, Fagundes et al. 2016). However, in a more recent and realistic perspective, biodiversity should be viewed and evaluated in ways that also embraces the extreme richness inherent in biotic interactions, including not only trophic relationships, but also aspects of life histories, biology and behavior of related species (Del-Claro et al. 2013, 2016, 2018).

Despite ubiquitous, the outcomes of each interaction vary depending on physical and biotic changes in the environment. Thus, there is no mutualism, for example, that will be ever and unconditionally a mutualism (Figure 2). Same parasitic or predatory relationships will change over evolutionary time modifying the results of the interactions (see Del-Claro and Torezan-Silingardi, 2012, for a review). For example, bees commonly act as pollinators of many plant species. Several of these plant species in Cerrado vegetation also possess extrafloral nectaries (EFNs), glands located outside flowers, in leaves, brackens and stems that attract ants to feed on its sugar rich nectar (Figure 2 ), that in counterpart protect the plants against natural enemies (Del-Claro et al. 2016, 2018). But ants can also visit flowers and ant visitation on flowers might be detrimental to plant reproduction, especially because pollinators might be deterred, expelled, and/or preyed upon by flower-visiting ants (Assunção et al. 2014). In a manipulative field experiment, Assunção et al. (2014) showed that just the ant shape and color on a flower can significantly reduce the visit of pollinators, leading to a dramatic indirect cost of a mutualism. The central tendency in ecological studies to explain these variations in the outcomes of biotic interactions is to suppose that the majority of meaningful functional diversity occurs at the level of the species and intraspecific variation is commonly ignored, including the major part of studies in this line performed in Cerrado vegetation (Del-Claro and Torezan-Silingardi 2012, Thompson 2013). Nevertheless, individuals are rarely identical and behavioral ecology, for example, has showed that consistent individual differences in personality and/or temperament may alter the roles that individuals play within populations and possibly communities (e.g. Filgueiras et al. 2018, Moura et al. 2018). Thus, the knowledge of individual aspects (including genetic variation) and natural history are fundamental to the study of biodiversity. We strongly recommend this type of guideline to future studies in cerrado ecosystem that intend to build the basis to its conservancy.

In this still new and promising pathway to really understand the mechanisms involved in our amazing biodiversity dawn the studies of ecological networks (Dáttilo and Rico-Gray 2018), studies that have used tools derived from graph theory to investigate the organization of ecological interactionsindifferentecosystemsaround theworld. In this sense, to add ecological networks studies to our knowledge about aspects of life histories, biology and behavior of related species, we need to search for useful tools and biological systems, to achieve success in a so complex scientific field. In the Cerrados, the advances have been made using background models, as ant-plant interactions. The variation in the outcomes of mutualism between ants and EFN-bearing plants is widely recognized (see Rico-Gray and Oliveira 2007). In ant-EFN plant interactions, from one community to others, the same plant species presents variation in internal (i.e. nutrition, phenology, nectar production and quality) and external factors (i.e. variations in meteorological and soil conditions) that direct influence the outcomes of each interaction (see DelClaro et al. 2016). Thus so, to Cerrado vegetation where these interactions are very common, an important future direction is to evaluate the role of 


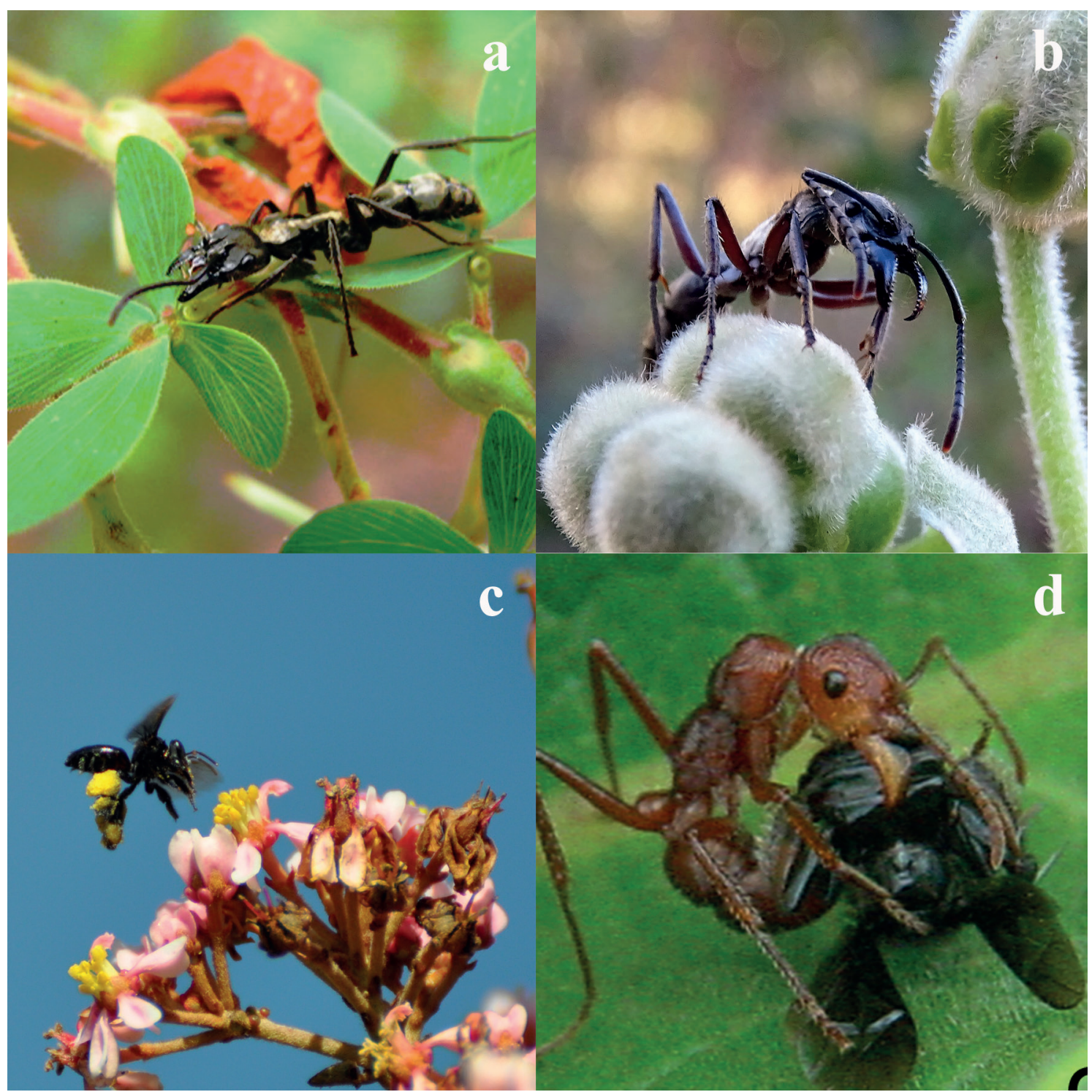

Figure 2 - Ants feed on different plant resources and extrafloral nectar (EFN) is the most common. Plant produces this secretion rich in water, sugar (fructose and sucrose), amino acids, and other substances in small quantities that attract ants that climb onto the plants and protected them against natural enemies, like herbivores (a - Neoponera villosa feeding on EFN in Inga vera, Leguminosae). This relationship is named mutualism, where both organisms benefit each other. However, these ants also need protein (the reason they protect the plants) and walk by all plant parts searching for animal food, including the inflorescences (b). But, plants need pollination to reproduce, what is related to other visitors like bees (c - Trigiona $\mathrm{sp}$ ). When ants casually find pollinators, they represent food, and the ants will attack then (d-Ectatomma tuberculatum preying on a Trigona asp), now prejudicing the plant reproduction. It represents an unexpected effect of a mutual interaction.

each partner within the multitrophic networks, in order to understand the ecological and evolutionary dynamics of interactive communities, usually rich in species and interactions. Are these systems results of coevolutionary process? May ant-plant systems in Cerrados shape a study model applied to other ecosystems where we intend to understand the communities' dynamic?

We suggest that Cerrado, like other tropical savannas, is a particularly important ecosystem in which we can direct efforts to explain what determines the major part of variation in the 
outcomes of species interactions. Could it be species identity, phenological variation over time, climatic changes, coevolution, or a combination of factors?

Climatic parameters are able to influence the timing of phenological events, affecting the degree of synchrony among plant species, their interactions, and reproductive success. In a world in quickly climatic change, integrating phenological investigations in the field with the existing theories and mathematical modeling may allow us to describe the possible maintenance and evolution of life histories in response to climate change. The Cerrados are an appropriate ecosystem to test and observe these important aspects to the biodiversity preservation. Recently, Vilela et al. (2018) working in the Cerrados of central Brazil, in Minas Gerais state, verified variations in climatic factors (temperature and precipitation) over a period of 10 years (2005-2014) and correlated them with the onset of flowering of four plant species. These authors also tested whether the observed phenological synchronization among species changed over time, affecting the herbivory and fruit set. With the field work background Vilela et al. (2018) developed a mathematical model to estimate the flower and fruit production in response to phenological changes for 5 years. In short, these authors integrated phenological investigations, ecological interactions among plants and animals in the Brazilian savanna with the existing theories and mathematical modeling. That allowed us to interpret different phenological synchronization degrees and enable us to describe the possible maintenance and evolution of life histories in response to climate change. This is an enormous and initial step to establish a plan to recover and preserve this endangered ecosystem.

The Cerrado, despite being an amazing, enormous, and very diverse ecosystem, where the development of the studies of biodiversity of interactions may open a window to the comprehension of the same processes in other biomes, is also an area which divides three of the largest South American water basins: those of the Amazon, Plate/Paraguay, and São Francisco rivers (see Oliveira-Filho and Ratter 2002). The major part of river sources of these basins is in the Veredas of Triângulo Mineiro, at Minas Gerais state. Thus, the Cerrado is not only a hot spot of biodiversity, but also a hot spot to water preservation in Central South America. Any effort to the real preservation of world biodiversity must consider the Cerrado.

\section{ACKNOWLEDGMENTS}

We thank Adalberto Luís Val and Vivaldo Mora Neto for reviews and comments in the original version of the manuscript. We also thank the Brazilian and French Academies of Science for the invitation for to participate in the Biodiversity Symposium. The authors thank to Conselho Nacional de Desenvolvimento Científico e Tecnológico (CNPq) and Fundação de Amparo à Pesquisa do Estado de Minas Gerais (Fapemig) for financial support.

\section{AUTHOR CONTRIBUTIONS}

Both authors contributed in all parts of the manuscript, since the development of the idea, composition of figures, writing and conclusions, equally.

\section{REFERENCES}

ASSUNÇÃO MA, TOREZAN-SILINGARDI HM AND DEL-CLARO K. 2014. Do ant visitors to extrafloral nectaries of plants repel pollinators and cause an indirect cost of mutualism? Flora 2: 244-249.

DÁTTILO W AND RICO-GRAY V. 2018. Ecological Networks in the Tropics: An Integrative Overview of Species Interactions from Some of the Most Species-Rich Habitats on Earth. ISBN: 978-3-319-68227-3. Springer, $201 \mathrm{p}$.

DEL-CLARO K AND TOREZAN-SILINGARDI HM. 2012. Ecologia das Interações Plantas-Animais: Uma Abordagem Ecológico-Evolutiva. Rio de Janeiro: Technical Books, $333 \mathrm{p}$. 
DEL-CLARO K, STEFANI V, LANGE D, VILELA AA, NAHAS L, VELASQUES M AND TOREZANSILINGARDI HM. 2013. The importance of natural history studies for a better comprehension of animal-plant interactions networks. Bioscence J 29: 439-448.

DEL-CLARO K, RICO-GRAY V, TOREZANSILINGARDI HM, ALVES-SILVA E, FAGUNDES R, LANGE D, DÁTILLO W, VILELA AA, AGUIRRE A AND RODRIGUEZ-MORALES D. 2016. Loss and gains in ant-plant interactions mediated by extrafloral nectar: Fidelity, cheats, and lies. Insectes Soc 63: 207-221.

DEL-CLARO K, LANGE D, TOREZAN-SILINGARDI HM, ANJOS DV, CALIXTO ES, DÁTTILO W AND RICO-GRAY V. 2018. The Complex Ant-Plant Relationship Within Tropical Ecological Networks In: Ecological Networks in the Tropics. $1^{\text {st }}$ ed., Dáttilo W and Rico-Gray V (Eds), Springer International Publishing, v.1, p. 59-71.

FAGUNDES R, DÁTTILO W, RIBEIRO SP, RICO-GRAY V AND DEL-CLARO K. 2016. Food source availability and interspecific dominance as structural mechanisms of ant-plant-hemipteran multitrophic networks. Arthropod Plant Interact 10(3): 207-220.

FILGUEIRAS RR, GOMES FCC, TIZO A, DEL-CLARO K AND TIZO-PEDROSO E. 2018. Cooperative foraging in neotropical pseudoscorpions: effects of prey changes on behavioral adjustments of colonies. Actha Ethologica 2018: https://doi.org/10.1007/s10211-018-0294-7.
GOTTSBERGER G AND SILBERBAUERGOTTSBERGER I. 2006. Life in the Cerrado: a South American Tropical Seasonal Ecosystem. Vol. I. Origin, Structure, Dynamics and Plant Use. - Reta, Ulm, 277 p.

MOURA RF, TIZO-PEDROSO E AND DEL-CLARO K. 2018. Colony size, habitat structure, and prey size shape the predation ecology of a social pseudoscorpion from a tropical savanna. Behavioral Ecology and Sociobiology, v.72, p. 103.

OLIVEIRA-FILHO AT AND RATTER JA. 2002. Vegetation physiognomies and woody flora of the cerrado biome, p. 91-120. In: Oliveira PS and Marquis RJ (Eds), The cerrados of Brazil: ecology and natural history of a neotropical savanna. Columbia University Press, New York, 398 p.

OLIVEIRA PS AND MARQUIS RJ. 2002. The cerrados of Brazil: Ecology and natural history of Neotropical savanna. Columbia University Press, New York, 398 p.

PEARSON DL. 1994. Selecting indicator taxa for the quantitative assessment of biodiversity. Philos Trans R Soc Lond B Biol Sci 345: 75-79.

RICO-GRAY V AND OLIVEIRA PS. 2007. The ecology and evolution of ant-plant interactions. The University of Chicago Press, Chicago.

THOMPSON JN. 2013. Relentless Evolution. University of Chicago Press, Chicago.

VILELA AA, DEL CLARO VTS, TOREZANSILINGARDI HM AND DEL-CLARO K. 2018. Arthropod-Plant Interactions 12: 215-227. 